Journal of Holistic and Health Sciences

Vol.2, No.1, Januari-juni 2018 |44

\title{
FAKTOR-FAKTOR YANG MEMPENGARUHI KEJADIAN ANEMIA PADA IBU HAMIL DI KECAMATAN JATILUHUR KABUPATEN PURWAKARTA
}

\author{
Lia Windari' ${ }^{1}$ Naintina Lisnawati ${ }^{2,4^{*}}$, Tomi Herutomo ${ }^{3}$ \\ 1,2,3 Sekolah Tinggi Ilmu Kesehatan Holistik \\ ${ }^{4}$ Bagian Gizi Fakultas Kesehatan Masyarakat Universitas Diponegoro \\ *Korespondensi: Jl. Veteran No.272 Ciseureuh Purwakarta, Email: naintinalisnawati@gmail.com
}

\begin{abstract}
ABSTRAK
Latar Belakang: Tingginya prevalensi anemia pada ibu hamil di Indonesia dapat mengakibatkan risiko melahirkan bayi berat badan lahir rendah (BBLR) dan prematur. Angka kejadian anemia pada ibu hamil di Kabupaten Purwakarta sebesar 65\%, sedangkan di Puskesmas Jatiluhur sebanyak 5,4\%.

Tujuan Penelitian: Menganalisis faktor-faktor yang berpengaruh terhadap kejadian anemia pada ibu hamil di Kecamatan Jatiluhur Kabupaten Purwakarta.

Metode: Desain penelitian ini adalah case control. Subjek penelitian adalah ibu hamil anemia di Kecamatan Jatiluhur Kabupaten Purwakarta yang berjumlah 34 orang. Pengumpulan data menggunakan kuesioner yang berisikan pertanyaan tentang karakteristik responden, jarak kehamilan, tingkat pendidikan, kunjungan antenatal care (ANC), pengetahuan, dan kepatuhan konsumsi tablet Fe. Analisis data menggunakan uji Chi-Square.

Hasil: Faktor-faktor yang berpengaruh terhadap kejadian anemia pada ibu hamil adalah umur $(p=0,002, \mathrm{OR}=1,956)$, asupan zat besi $(p=0,006, \mathrm{OR}=0,16)$, tingkat pendidikan $(p=0,020, \mathrm{OR}=$ $0,07)$, pengetahuan ( $p=0,001, \mathrm{OR}=1,266)$, dan kunjungan ANC $(p=0,001, \mathrm{OR}=2,04)$ sedangkan jarak kehamilan $(p=0,619, \mathrm{OR}=0,942)$, asupan protein $(p=0,493, \mathrm{OR}=1,193)$, paritas $(p=0,494$, $\mathrm{OR}=1,060)$, LILA $(p=0,086, \mathrm{OR}=0,658)$ dan kepatuan konsumsi $\mathrm{Fe}(p=0,0571, \mathrm{OR}=0,07)$ tidak berpengaruh dengan kejadian anemia pada ibu hamil.

Simpulan: Faktor-faktor yang mempengaruhi kejadian anemia pada ibu hamil di Kecamatan Jatiluhur Kabupaten Purwakarta yaitu umur, asupan zat besi, pendidikan, pengetahuan, dan kunjungan ANC.
\end{abstract}

Kata kunci: anemia, faktor-faktor yang mempengaruhi anemia, ibu hamil

\begin{abstract}
Background: High prevalence of anaemia among pregnant women in Indonesia increasing risk of giving birth to low birth weight babies (LBW) and premature. The prevalence of anaemia among pregnant women in Purwakarta Regency was 65\% in 2016, whereas in Jatiluhur Health Center reach $5,4 \%$.
\end{abstract}

Objective: Analyze factors that influence the incidence of anaemia among pregnant women in Jatiluhur, Purwakarta.

Method: This research used case control design. Subjects were 34 anaemia pregnant women in Jatiluhur Subdistrict, Purwakarta Regency. Data collection using a questionnaire containing questions about characteristics of respondents, distance of the pregnancy, level of education, antenatal care (ANC) visit, knowledge, and adherence of Fe consumption. Analysis data using ChiSquare test.

Result: Factors that influence the incidence of anaemia in pregnant women were age ( $p=0,002$, $O R=1,956)$, iron intake $(p=0,006, O R=0,16)$, level of education $(p=0,020,0 R=0,07)$, knowledge $(p=0,001, O R=1,266)$, and $A N C$ visit $(p=0,001, O R=2,04)$ whereas the distance of pregnancy $(p=0,619$, OR=0,942), protein intake $(p=0,493$, OR=1,193), parity $(p=0,494, O R=1,060)$, LILA ( $p=0,086,0 R=0,658)$ and adherence of Fe consumption ( $p=0,0571,0 R=0,07)$ have no influence with the incidence of anaemia in pregnant women.

Conclusion: Factors that influence the incidence of anaemia in pregnant women in Jatiluhur Subdistrict Purwakarta Regency were iron intake, age, level of education, knowledge, and ANC visit.

Keywords: anaemia, factors that influence anemia, pregnant women 


\section{PENDAHULUAN}

Anemia pada ibu hamil disebut "Potential danger of mother and child". Berbagai akibat yang ditimbulkan oleh anemia pada masa kehamilan antara lain terjadinya abortus, partus, prematur, dan perdarahan post partum karena infeksi. Oleh karena itu, anemia memerlukan perhatian serius dari semua pihak yang terkait dalam pelayanan kesehatan. ${ }^{1}$ Prevalensi Anemia pada ibu hamil di Kabupaten Purwakarta sebanyak 3073 orang atau $65,0 \%$, capaian ini belum sesuai dengan target yang di tentukan oleh dinas kesehatan yaitu 85\% yang tidak mengalami anemia. Anemia pada ibu hamil juga meningkatkan resiko kelahiran prematur atau berat lahir rendah (BBLR), serta risiko pendarahan sebelum dan saat persalinan yang dapat menyebabkan kematian ibu dan bayinya bila ibu hamil tersebut menderita anemia berat. ${ }^{2}$

Berdasarkan penelitian di wilayah Puskesmas Bajeng Gowa diperoleh hasil bahwa pengukuran LILA mempengaruhi status gizi ibu hamil sebesar $(66,0 \%)$ status gizi kurang dengan ukuran LILA $<23,5 \mathrm{~cm}$ mengalami anemia saat hamil, dan sebanyak 34 orang $(34,0 \%)$ status gizi ibu hamil cukup, oleh karena itu LILA yang kurang dari 23,5 cm mempengaruhi anemia pada ibu hamil, kurangnya faktor pengetahuan ibu tentang anemia dan tablet $\mathrm{Fe}$ mempengaruhi sebesar 58 orang $(58,0 \%)$, dan ibu hamil yang memiliki pengetahuan yang cukup sebesar 42 orang (42,0\%). Hal ini menunjukkan bahwa umur, LILA dan pengetahuan ibu sangat penting untuk mengurangi jumlah anemia pada ibu hamil. ${ }^{3}$ Berdasarkan eneliti tertarik untuk melakukan penelitian tentang "Faktorfaktor yang berpengaruh terhadap Kejadian Anemia pada Ibu Hamil di Kecamatan Jatiluhur Kabupaten Purwakarta".

\section{METODE PENELITIAN}

Penelitian ini menggunakan desain case control. Besar responden yang diambil sebanyak 34 subjek. Variabel terikat pada penelitian ini adalah anemia pada ibu hamil, sedangkan variabel bebas adalah umur, pendidikan ibu, jarak kehamilan, pengetahuan, status gizi, paritas, kepatuhan konsumsi fe, kunjungan kehamilan, asupan protein, dan asupan zat besi. Pengumpulan data penelitian menggunakan kuesioner. Analisis data menggunakan uji Chi-Square.

\section{HASIL PENELITIAN}

Tabel 1. Faktor-Faktor yang Berpengaruh dengan Kejadian Anemia Ibu hamil di Kecamatan Jatiluhur Kabupaten Purwakarta

\begin{tabular}{|c|c|c|c|c|c|c|c|}
\hline \multicolumn{8}{|c|}{ Anemia ibu hamil } \\
\hline \multirow[t]{2}{*}{ No } & \multirow[b]{2}{*}{ Variabel } & \multicolumn{2}{|c|}{ Anemia } & \multicolumn{2}{|c|}{ Tidak anemia } & \multirow[b]{2}{*}{$p$} & \multirow[b]{2}{*}{ OR } \\
\hline & & $\mathrm{n}$ & $\%$ & $\mathrm{n}$ & $\%$ & & \\
\hline \multirow[t]{3}{*}{1} & Umur & & & & & & \\
\hline & $\begin{array}{l}\text { a. Tidak berisiko(20 tahun-35 } \\
\text { tahun) }\end{array}$ & 20 & 58,8 & 31 & 91,2 & $0,002^{\mathrm{a}}$ & 1,956 \\
\hline & $\begin{array}{l}\text { b. Resiko tinggi }(<20 \text { tahun dan }> \\
35 \text { tahun) }\end{array}$ & 14 & 41,2 & 3 & 8,8 & & \\
\hline \multirow[t]{3}{*}{2} & Jarak kehamilan & & & & & & \\
\hline & a. Tidak berisiko $(\geq 2$ tahun & 33 & 97,12 & 32 & 94,15 & $0,619^{\mathrm{b}}$ & 0,942 \\
\hline & b. Berisiko $(<2$ tahun $)$ & 1 &, 9 & 2 &, 9 & & \\
\hline \multirow[t]{3}{*}{3} & Paritas & & & & & & \\
\hline & a. Tidak berisiko (< 2 orang) & 32 & 94,15 & 33 & 97,12 & $0,494^{b}$ & 1,060 \\
\hline & b. Berisiko(> 2 orang & 2 &, 9 & 1 &, 9 & & \\
\hline \multirow[t]{3}{*}{4} & Asupan protein & & & & & & \\
\hline & a. $\geq$ median $43,5 \mathrm{gr}$ & 1 & 2,9 & 3 & 8,8 & $0,394^{b}$ & 1,193 \\
\hline & b. $<$ median $43,5 \mathrm{gr}$ & 33 & 97,1 & 31 & 91,2 & & \\
\hline \multirow[t]{3}{*}{5} & Asupan zat besi & & & & & & \\
\hline & a. $\geq$ median $13,5 \mathrm{mg}$ & 4 & 11,88 & 31 & 91,2 & $0,006^{\mathrm{b}}$ & 0,16 \\
\hline & b. < median $13,5 \mathrm{mg}$ & 30 & 8,2 & 3 & 8,8 & & \\
\hline
\end{tabular}




\begin{tabular}{|c|c|c|c|c|c|c|c|}
\hline 6 & $\begin{array}{l}\text { LILA } \\
\text { a. } \geq 23,5 \mathrm{~cm} \\
\text { b. }<23,5 \mathrm{~cm}\end{array}$ & $\begin{array}{c}26 \\
8\end{array}$ & $\begin{array}{c}47,15 \\
2,9\end{array}$ & 1915 & $\begin{array}{c}55,94 \\
4,1\end{array}$ & $0,086^{\mathrm{a}}$ & 0,658 \\
\hline 7 & Pendidikan & & & & & & \\
\hline & $\begin{array}{l}\text { a. Pendidikan tinggi (SMA,SI) } \\
\text { b. Pendidikan dasar (SD,SMP) }\end{array}$ & $\begin{array}{l}10 \\
24\end{array}$ & $\begin{array}{c}29,47 \\
0,6\end{array}$ & $\begin{array}{c}4 \\
30\end{array}$ & $\begin{array}{c}11,88 \\
8,2\end{array}$ & $0,020^{\mathrm{a}}$ & 0,07 \\
\hline 8 & Pengetahuan & & & & & & \\
\hline & $\begin{array}{l}\text { a. } \text { Baik }(>=\text { median }) \\
\text { b. Kurang }(<\text { median })\end{array}$ & $\begin{array}{c}28 \\
6\end{array}$ & $\begin{array}{c}82,41 \\
7,6\end{array}$ & $\begin{array}{c}32 \\
2\end{array}$ & $\begin{array}{c}94,15 \\
, 9\end{array}$ & $0,001^{\mathrm{a}}$ & 1,266 \\
\hline 9 & $\begin{array}{l}\text { Kunjungan Antenatal care } \\
\text { a. Baik }(>4 \text { kali }) \\
\text { b. Tidak baik }(<4 \text { kali })\end{array}$ & $\begin{array}{l}15 \\
19\end{array}$ & $\begin{array}{l}44,1 \\
55,9\end{array}$ & $\begin{array}{c}1 \\
33\end{array}$ & $\begin{array}{c}2,9 \\
97,1\end{array}$ & $0,001^{a}$ & 2,04 \\
\hline 10 & $\begin{array}{l}\text { Kepatuhan konsumsi Fe } \\
\text { a. Patuh } \\
\text { b. Tidak patuh }\end{array}$ & $\begin{array}{c}4 \\
30\end{array}$ & $\begin{array}{l}11,8 \\
88,2\end{array}$ & $\begin{array}{l}10 \\
24\end{array}$ & $\begin{array}{l}29,4 \\
70,6\end{array}$ & $\begin{array}{c}0,0571 \\
\mathrm{a}\end{array}$ & 0,07 \\
\hline
\end{tabular}

aChi Square Test

${ }^{b}$ Fisher Exact Tes

\section{PEMBAHASAN}

\section{Pengaruh umur dengan kejadian anemia pada ibu hamil}

Umur dalam penelitian ini berpengaruh dengan kejadian anemia pada ibu hamil. Dari hasil penelitian diketahui bahwa umur responden berpengaruh terhadap kejadian anemia pada ibu hamil. $41,2 \%$ merupakan kelompok umur yang memiliki resiko tinggi, sedangkan 58,8\% tidak berisiko. Hasil ini serupa dengan penelitian yang dilakukan siti asyirah (2012) di kecamatan gowa depok yang menyebutkan bahwa tidak ada hubungan yang signifikan antara umur dengan kejadian anemia pada ibu hamil. Dari hasil penelitian ini menunjukkan ada pengaruh yang bermakna antara umur ibu hamil dengan kejadian anemia dengan nilai $\mathrm{P}$ Value $=0,619, \quad O R=1,956$ hasil penelitian menunjukkan prevalensi anemia lebih banyak ditemukan pada responden kelompok umur berisiko dibandingkan kelompok umur tidak berisiko. Hal ini membuktikan bahwa ibu hamil yang berumur $<20$ tahun dan $>35$ tahun lebih berisiko untuk terkena anemia.

\section{Pengaruh jarak kehamilan dengan kejadian anemia pada ibu hamil}

Jarak kehamilan dalam penelitian ini tidak ada pengaruh dengan kejadian anemia pada ibu hamil, sebesar 2,9\% ibu mempunyai jarak kehamilan berisiko dan $97,1 \%$ tidak berisiko ( $p=0,619,0 \mathrm{R}=0,942)$. Penelitian ini serupa dengan penelitian yang dilakukan salmariantity (2012) di indragiri hilir yang menyatakan bahwa tidak ada hubungan antara jarak kehamilan dengan kejadian anemia pada ibu hamil dimana $(p=0.52)$. Dari hasil penelitian menunjukkan tidak ada pengaruh yang bermakna antara jarak kehamilan dengan kejadian anemia pada ibu hamil dengan nilai ( $p=0,619,0 R=0,942)$ karena pada penelitian ini di temukan banyaknya ibu hamil dengan jarak kehamilan $\geq 2$ taun sebesar $(94,1 \%)$ tidak berisiko.

\section{Pengaruh paritas dengan kejadian anemia pada ibu hamil}

Paritas dalam penelitian ini tidak berpengaruh dengan kejadian anemia pada ibu hamil. Dari hasil penelitian diketahui bahwa yang termasuk ke dalam kategori berisiko adalah $5,9 \%$, dan 94,1\% termasuk dalam paritas tidak berisiko dengan nilai $(p=0,494, \quad 0 \mathrm{R}=1,060)$. Hasil ini serupa dengan penelitian Darmawan (2003) menemukan bahwa paritas tidak berhubungan dengan kejadian anemia pada ibu hamil. Hasil yang sama ditunjukkan juga oleh penelitian yang dilakukan Dewi (2009) dan Wardhani (2011) bahwa tidak ada hubungan yang bermakna antara paritas dengan anemia pada ibu hamil. Terjadinya pengaruh yang tidak bermakna disebabkan oleh jumlah responden dengan paritas $\leq 2$ orang sebanyak $(94,1 \%)$ tidak berisiko.

\section{Pengaruh asupan protein dengan kejadian anemia pada ibu hamil}

Hasil penelitian menunjukkan bahwa tidak ada pengaruh asupan protein dengan kejadian anemia pada ibu hamil $(\mathrm{p}=0,493$, $\mathrm{OR}=1,193$ ). Semua responden memiliki asupan protein yang kurang. Hasil ini 
serupa dengan penelitian Murtini (2004) di Bantimurun kabupaten maros diperoleh bahwa ibu hamil dengan asupan protein $(66,7 \%)$ tergolong kategori asupan protein cukup, (58,1\%) memiliki asupan protein yang kurang. Hasil uji chi square menunjukkan nilai $(\mathrm{p}=\geq 0,05)$ yaitu sebesar $(0,649)$, sehingga dapat disimpulkan bahwa tidak ada pengaruh asupan protein dengan kejadian anemia pada ibu hamil.

Pengaruh asupan zat besi dengan kejadian anemia pada ibu hamil

Hasil penelitian bahwa ada pengaruh asupan zat besi terhadap kejadian anemia pada ibu hamil $(p=0,006,0 \mathrm{R}=0,16) \cdot 88,2 \%$ responden memiliki asupan zat besi kurang, sedangkan $11,8 \%$ memiliki asupan zat besi cukup. Hasil uji statistik menunjukkan nilai $\mathrm{OR}<1$ tetapi nilai $\mathrm{P}$ Value menunjukkan $\leq$ 0,05 sehingga ada pengaruh yang bermakna antara asupan zat besi dengan anemia pada ibu hamil. Penelitian lain menunjukan hasil yang sama, yaitu penelitian Purba (2006) menyatakan bahwa ada pengaruh asupan zat besi terhadap kejadian anemia pada ibu hamil. Penelitian tersebut menunjukkan bahwa $(86,7 \%)$ responden dengan asupan zat besi kurang mengalami anemia, sedangkan responden dengan asupan zat besi cukup sebanyak $(69,9 \%)$ mengalami anemia dengan nilai $(p=0,003)$.

\section{Pengaruh LILA dengan kejadian anemia pada ibu hamil}

Hasil penelitian bahwa pengaruh LILA dengan kejadian anemia pada ibu hamil dengan nilai hasil uji statistik terbukti tidak signifikan $(p=0,086, \quad \mathrm{OR}=0,658)$ artinya tidak ada pengaruh antara LILA dengan kejadian anemia pada ibu hamil. Wijanto (2006) dan Wardhi (2010) menyebutkan bahwa ada hubungan yang bermakna antara ukuran LILA dengan status anemia ibu hamil. Dari hasil penelitian bahwa LILA responden yang $\geq 23,5 \mathrm{~cm}$ sebanyak $(47,1 \%)$. Untuk mengetahui kelompok berisiko Kekurangan Energi Kronik (KEK) di perlukan penukuran LILA kepada ibu hamil, apabila ukuran LILA kurang dari ambang batas $23,5 \mathrm{~cm}$ berarti wanita tersebut berisiko KEK.

\section{Pengaruh pendidikan dengan kejadian anemia pada ibu hamil}

Perbedaan proporsi tingkat pendidikan dalam penelitian ini adalah
$(70,6 \%)$ ibu hamil dengan tingkat pendidikan dasar dan $(29,4 \%)$ ibu hamil dengan tingkat pendidikan tinggi yang menderita anemia denan nilai $(p=0,020$, $\mathrm{OR}=0,07)$. Hasil uji statistik menunjukkan bahwa nilai $P$ Value $\leq 0,05$ sehingga adanya pengaruh pendidikan terhadap kejadian anemia pada ibu hamil, maka semakin tinggi pendidikan formal diharapkan semakin tinggi pula tingkat pendidikan kesehatan karena tingkat pendidikan kesehatan merupakan bentuk intervensi terutama terhadap faktor perilaku kesehatan. Menurut penelitian Widarti (2008) di Kota Cirebon mendapatkan hasil bahwa tingkat pendidikan tidak berhubungan secara signifikan dengan kejadian anemia pada ibu hamil.

\section{Pengaruh pengetahuan dengan kejadian anemia pada ibu hamil}

Pengetahuan dalam penelitian ini ada pengaruh teradap kejadian pada ibu hamil anemia $\quad(p=0,001, \quad 0 R=1,266) . \quad 17,6 \%$ responden memiliki tingkat pengetahuan kurang, sedangkan $82,4 \%$ tingkat pengetahuan baik dan tidak ada yang mempunyai tingkat pengetahuan buruk. Nilai OR $\geq 1$ menunjukkan bahwa pengetahuan ibu mempunyai hubungan yang bermakna terhadap kejadian anemia pada ibu hamil. Dalam penelitian ini, peneliti beranggapan bahwa apabila ibu hamil memiliki pengetahuan baik tentang anemia gizi besi selama hamil meliputi penyebabnya, bahayanya bagi ibu dan bayi dalam kandungan dan cara pencegahannya tentu ibu hamil tersebut akan menjaga kesehatannya selama hamil dengan lebih baik. Antara lain dengan memakan makanan yang banyak mengandung zat besi dan mengkonsumsi sampai habis tablet $\mathrm{Fe}$ yang diterimanya. Karena setiap ibu hamil mengharapkan untuk melairkan dengan selamat dan memiliki anak yang sehat dan cerdas.

Pengaruh kunjungan Antenatal care dengan kejadian anemia pada ibu hamil

Pada penelitian ini jumlah ibu hamil dengan Antenatal care $<4$ kali sebesar $44,1 \%$, sedangkan ibu hamil dengan antenatal care $>4$ kali sebesar $55,9 \%$. Hasil uji statistik menunjukkan nilai $(\mathrm{p}=0,001$, $\mathrm{OR}=2,04$ ). Nilai $\mathrm{OR}$ menunjukkan $\geq 1$ Maka dapat disimpulkan bahwa ada pengaruh 
yang sangat signifikan atau 2 kali lipat berisiko terhadap kejadian anemia pada ibu hamil. Pemeriksaan kehamilan dianjurkan 4 kali dalam kondisi kehamilan normal. Standar Antenatal Care (ANC) dikenal dengan 10T yaitu timbang berat badan, ukur tinggi badan, tekanan darah, status gizi, pemeriksaan tinggi pundus, denyut jantung, berikan Tetanus toxoid, tablet tambah darah, tes lab, tes penyakit kelamin dan temu wicara dalam rangka persiapan rujukan. Pemeriksaan kehamilan secara teratur merupakan upaya untuk mendeteksi lebih dini bahaya atau komplikasi yang bisa terjadi dalam kehamilan seperti anemia defisiensi besi pada ibu hamil.

Pengaruh kepatuhan konsumsi Fe dengan kejadian anemia pada ibu hamil

Dari hasil penelitian ini diperoleh ibu hamil yang patuh mengkonsumsi tablet $\mathrm{Fe}$ sebesar 11,8\% sedangkan ibu hamil yang tidak patuh mengkonsumsi tablet $\mathrm{Fe}$ sebesar $88,2 \%$. Hasil uji statistik chi-square tidak menunjukkan adanya pengaruh konsumsi tablet Fe dengan kejadian anemia pada ibu hamil ( $p=0,057$; OR=0,7). Hasil ini serupa dengan penelitian yang dilakukan oleh Herlina (1999) yaitu tidak adanya hubungan kepatuhan konsumsi Fe dengan kejadian anemia pada ibu hamil sebanyak $(90,1 \%)$ ibu hamil yang tidak cukup mengkonsumsi Fe menderita anemia dan yang mengkonsumsi $\mathrm{Fe}$ cukup sebesar $(74,1 \%)$ denan nilai PValue $>0,5$.

\section{SIMPULAN}

Anemia merupakan masalah kesehatan yang sering diderita oleh ibu hamil. Hal ini dapat menyebabkan munculnya beberapa masalah kesehatan lain, seperti bayi lahir premature dan bayi lahir dengan BBLR. Hasil penelitian ini menunjukkan beberapa faktor yang mempengaruhi kejadian anemia pada ibu hamil di Kecamatan Jatiluhur Kabupaten Purwakarta yaitu umur, asupan zat besi, pendidikan, pengetahuan, dan kunjungan ANC.

\section{DAFTAR PUSTAKA}

1. Manuaba Ida Bagus Gede. 2001. Ilmu Kebidanan, Penyakit Kandungan dan keluarga Berencana Untuk Pendidikan Bidan. Jakarta: EGC.

2. Prawirohardjo. 2010. Ilmu Kebidanan. Jakarta: YBS.

3. Asyirah, Siti. 2012. Faktor-faktor yang berhubungan dengan anemia pada ibu hamil di wilayah kerja puskesmas bajeng kecamatan bajeng kabupaten goa. Depok: Universitas Indonesia.

4. Salmariantity. 2012. Faktor-faktor yang berhugungan dengan anemia pada ibu hamil di wilayah kerja puskesmas gajah mada tembilahan kapubaten Indragiri hilir tahun. Depok: Universitas Indonesia.

5. Murtini.2004. Efektifitas Suplementasi Tablet Besi dan Vitamin C Terhadap Kadar Hemoglobin Ibu Hamil di Wilayah Kerja Puskesmas Bantimurung Kabupaten Maros.

6. Purba. 2006. Faktor-faktor yang Berhubungan dengan Status Anemia Gizi Besi pada Ibu Hamil Pengunjung Puskesmas Wilayah Kota Pekanbaru Tahun 2006. Depok : FKM UI.

7. Wijanto, Darma. 2006. Faktor-faktor yang Berhubungan dengan Kejadian Anemia Ibu hamil di Kota Cirebon. Depok: FKM UI.

8. Widarti. 2008. Faktor-faktor yang Berpengaruh terhadap Anemia pada Ibu hamil di Kota Cirebon. Depok: FKM UI.

9. Herlina. 1999. Faktor Resiko Kejadian Anemia Pada Ibu Hamil Di Wilayah Kerja Puskesmas Bogor. Jakarta: Bppsdmk. 